\title{
MOTIVÁCIA K ČÍTANIU A ČITATELSKÉ PREFERENCIE ADOLESCENTOV
}

\author{
Nika Konrádyová, Miriam Slavkovská
}

\begin{abstract}
Abstrakt
Ciel'om výskumu bolo popísanie motívov, ktoré adolescentov vedú $\mathrm{k}$, respektíve brzdia v čítaní, ako aj zistenie možných rozdielov v motivácii a preferenciách žánrov z hl'adiska veku. Výskumný súbor tvorilo 375 respondentov, z čoho čitatel'ov bolo 130 (34,66 \%). Motivácia k čítaniu bola meraná prostredníctvom dotazníka Motivations for Reading Questionnaire (Wigfield \& Guthrie, 1997). Motívy, ktoré vedú respondentov k čítaniu, respektíve ich od čítania odrádzajú, boli zist’ované otvorenými otázkami. Výsledky ukázali, že medzi staršími a mladšími adolescentmi sa $\mathrm{v}$ rámci motivácie $\mathrm{k}$ čítaniu nenachádzajú rozdiely. K najčastejším motívom, ktoré vedú mladších respondentov k čítaniu kníh, patria: získavanie nových informácii z kníh, skutočnost', že čítanie považujú za zábavnú a zaujímavú aktivitu a súčasne za možnost' na chvíl'u uniknút' z reality. U starších dominovalo získavanie nových informácii, možnost' oddychu a únik z reality. V skupine nečítajúcej mládeže mladší respondenti uviedli, že nečítajú hlavne preto, lebo ich táto aktivita nebaví, knihy považujú za nudné a nechce sa im. Starších adolescentov od čítania odrádza presvedčenie, že čítanie je nudná aktivita a d’alším významným dôvodom je nedostatok času. Medzi mladšími čitatel'mi sú populárne dobrodružné romány, fantasy a dievčenské romány. U starších čitatel'ov dominujú žánre podobné, a to žáner dobrodružný, fantasy a detektívny.
\end{abstract}

Kl'účové slová: čítanie, motivácia, žánrové preferencie, mladší adolescenti, starší adolescenti

\section{READING MOTIVATION AND READING PREFERENCES OF ADOLESCENTS}

\begin{abstract}
The aim of this study was to describe motives that lead adolescents to read, or which make them refuse to read. Furthermore, it aimed to find out potential differences in motivation and reading preferences due to age group. Totally 375 respondents participated in this study from which 130 (34,66\%) were readers. Reading motivation was measured by the Motivations for Reading Questionnaire (Wigfield \& Guthrie, 1997). Motives that lead adolescents to read or which make them refuse to read were detected with open questions. Results show that there are no differences between younger and older adolescents in reading motivation. The most common reading motives in younger readers were: reaching new information from books, opinion, that reading is a funny and interesting activity and reading represents an opportunity to escape from the reality for a while. In the group of older adolescents were most common motives reaching new information, the way how to relax and escape from the reality. Nonreading younger adolescents refuse to read because they are not interested in reading, they consider the book boring and they do not have the will to read. Older adolescents do not read because they consider reading as a boring activity and they do not have enough time for it. The most popular genres among younger readers are the adventurous genre, fantasy, and novels for girls. Older readers prefer the adventurous genre, fantasy, and detective novels.
\end{abstract}

Keywords: reading, motivation, genre preferences, younger adolescents, older adolescents

Došlo: 29. 5. 2019

Schváleno: 15. 1. 2021 


\section{Úvod}

Výskumom zameraným na skúmanie motivácie k čítaniu sa venuje pozornost' už niekol'ko desat'ročí. Ich ciel'om je odhalenie osobných motívov jednotlivca ako aj motívov plynúcich z okolia, ktoré vedú žiakov k tomu, aby vo svojom vol'nom čase čítali knihy. Dôvodom pre rozsiahly výskum v tejto oblasti je skutočnost', že boli dokázané lepšie výsledky vo verbálnej fluencii, rozsahu slovnej zásoby, schopnosti pracovat's textom a podobných zručnostiach u žiakov, ktorí vo svojom vol'nom čase často čítali knihy (McGeown et al., 2015; Morgan \& Fuchs, 2007; Najvarová, 2008 a pod.), pričom tieto zručnosti boli žiakom nápomocné aj pri dosahovaní lepších študijných výsledkov v porovnaní s nečítajúcimi rovesníkmi. Nedostatkom týchto výskumov je, že sa zameriavajú len na vekovú kategóriu žiakov od šiestich do dvanástich rokov a ostatným vekovým kategóriám sa venuje pozornost' len ojedinele. Ciel'om tohto výskumu je preto preskúmat' motiváciu k čítaniu u starších adolescentov študujúcich na stredných školách a porovnat' ju s motiváciou žiakov druhého stupňa základných škôl. Pozornost' bude orientovaná aj na dôvody, pre ktoré jednotlivci vo svojom vol'nom čase čítajú, respektíve nečítajú, a na žánre preferované čítajúcimi respondentmi.

\section{Čítanie}

Čítanie je definované ako multidimenzionálna, ciel'ovo - orientovaná sociokultúrna aktivita (Conradi et al., 2014). Patrí k najdôležitejším a nevyhnutným činnostiam, ktoré sa jednotlivec má naučit' (De Naeghel et al., 2012) a ktoré využíva počas celého svojho života. Považuje sa za jeden z najdôležitejších a najzákladnejších spôsobov osvojovania si vedomostí (Pečjak \& Peklaj, 2006; Yogurtcu, 2013), pričom od tejto schopnosti nezávisia len akademické úspechy jednotlivca a následné úspechy v povolaní, ale aj úspechy bežného dňa (De Naeghel et al., 2014; Abdullah et al., 2012).

V rámci tejto práce sa však nebude nazerat' na čítanie ako na aktivitu, ktorej podstatou je schopnost' prijat' informácie z písaného textu, ale ako na aktivitu, ktorej sa jednotlivci venujú vo svojom vol'nom čase, ktorá spočíva v častom čítaní rozsiahleho textového materiálu, či sa už jedná o knihy alebo o tematické časopisy.

Štúdie uskutočnené za posledné obdobie dokázali, že práve takéto čítanie má priaznivý vplyv na viacero oblastí (Najvarová, 2008), no najväčšia pozornost' sa venovala tej školskej. V rámci nich sa ukázalo, že čítanie výraznou mierou ovplyvňuje školské zručnosti. Množstvo času stráveného čítaním má významný vplyv na rýchle rozoznávanie slov (čo platí hlavne pre žiakov na prvom stupni základných škôl) (Morgan \& Fuchs, 2007; De Naeghel et al., 2012), vývin verbálnej fluencie (McGeown et al., 2015; Morgan \& Fuchs, 2007), rýchlosti v čítaní (McGeown et al., 2015), nárastu čitatel'ských zručností (McGeown et al., 2015), nárastu slovnej zásoby (Morgan \& Fuchs, 2007), skvalitnenie schopnosti správne text analyzovat' a tým pádom narastá aj porozumenie čítanému textu (McGeown et al., 2015; Morgan \& Fuchs, 2007; De Naeghel et al., 2012; Abdullah et al., 2012; Paige, 2011; Wang \& Guthrie, 2004). Aj výskumy v česko-slovenskom prostredí poukázali na to, že silná záluba v čítaní sa spája s vysokým skóre v testoch čitatel'skej gramotnosti žiakov (Najvarová, 2008; Homolová, 2008). Adolescenti, ktorí vo vol'nom čase čítajú, zvyknú byt' počas čítania kognitívne aktívnejší a nakoniec dosiahnu hlbšie pochopenie textu, viac si z textu pamätajú a tým pádom vedia aj lepšie sumarizovat' ako ich ostatní spolužiaci (McGeown et al., 2015). 
K d'alším benefitom čítania patrí stimulovanie fantázie (Wilson \& Casey, 2007) a tak isto má vplyv aj na vývin intelektu ako takého (McKool, 2007; Morgan \& Fuchs, 2007), nehovoriac o tom, že žiaci, ktorí sa venujú čítaniu vo svojom vol’nom čase častejšie, dosahujú aj lepšie akademické výsledky (Pečjak \& Peklaj, 2006; Wilson \& Casey, 2007; Lee \& Jonson-Reid, 2016). Najvarová (2008) túto problematiku rozvíja a poukazuje na to, že čím je spektrum materiálov, ktoré jednotlivec číta, väčšie, tým je vyššie aj jeho skóre v testoch čitatel'skej gramotnosti. K rovnakým výsledkom vedie aj to, ak jednotlivci čítajú hlavne knihy a komixy v porovnaní s časopismi a novinami (Najvarová, 2008).

Pre potreby tejto práce sa čitatel' nedefinuje len ako osoba gramotná, čiže tá, ktorá vie čítat' a písat', vnímat' a rozumiet' zobrazenému textu. Čitatelia sú v tejto práci definovaní ako zanietení jednotlivci čítajúci knihy zo svojej vlastnej iniciatívy, z vlastného záujmu a pre radost' (De Naeghel et al., 2014; Wang \& Guthrie, 2004). Takýto jednotlivci majú vyššiu motiváciu čítat', to platí pre rôzny vek a pohlavie (Pečjak \& Košir, 2008; Lau, 2009), čítanie považujú za zaujímavé a dôležité (Pečjak \& Košir, 2008), čo sa prejaví aj tým, že ním strávia viac času a na túto aktivitu sú ochotní obetovat' vel'a energie (McGeown et al., 2015; Guthrie et al., 2007). Sú zvedaví a neostávajú pri jednom žánri, ale aktívne skúšajú nové (De Naeghel et al., 2014). Sami vyberajú to, čo budú čítat', dokonca majú k určitým témam silný osobný vzt'ah (Guthrie et al., 2007). Č́tanie považujú za hodnotný spôsob trávenia vol'ného času (Wilson \& Casey, 2007), aktívne ho vyhl'adávajú a dajú mu prednost' pred inými aktivitami. Zanietení čitatelia budú radšej čítat' knihy ako krátke texty a dajú prednost' knihe v tlačenej podobe ako v tej digitálnej (McGeown et al., 2015). Sebaobraz o sebe ako o čitatel'och majú vyšší ako ostatní a čítanie si viac cenia (McKool, 2007; Chiu \& Chow, 2010). Častým čitatel'om kníh neprináša čítanie len radost', ale vedia využit' svoje vedomosti z čítania a naplnit' tak svoje osobné ciele, túžby a úmysly (Lau, 2009; De Naeghel et al., 2014; RoeschlHeils et al., 2003).

\section{Motivácia}

Motivácia čítat' je pokladaná za jeden z najdôležitejších faktorov ovplyvňujúcich čítanie (Peklaj \& Pečjak, 2009). Môže byt’ definovaná ako súbor osobných predstáv, hodnôt, potrieb a ciel’ov, ktoré jednotlivec má $\mathrm{v}$ súvislosti s textom určeným na čítanie, procesom čítania a jeho výsledkami (Pitcher et al., 2007; Abdullah et al., 2012; De Naeghel et al., 2012; Pečjak \& Košir, 2008). Zohráva dôležitú úlohu pri vývine čítania (Lau, 2009). Ovplyvňuje vol’bu materiálu na čítanie (Pitcher et al., 2007), množstvo prečítaného textu a frekvenciu čítania vo vol'nom čase (De Naeghel et al., 2012; Morgan \& Fuchs, 2007; Edmunds, 2003).

Motivácia sa vo všeobecnosti delí na vonkajšiu a vnútornú. Napriek svojej zrejmej odlišnosti nepredstavujú dva póly jedného kontinua, ale vzájomne sa dopíňajú (Paige, 2011). Podl'a Guthrieho a kolektívu (2007) je to práve kombinácia vonkajšej a vnútornej motivácie, ktorá vysvetl'uje väčšiu proporciu kolísania v množstve času, ktorý strávia žiaci čítaním, ako keby boli jednotlivé motivácie brané do úvahy samostatne (Lau, 2009).

Jednotlivec, ktorého vonkajšia motivácia je silná, nečíta pre čítanie samo (Pečjak \& Peklaj, 2006; Wigfield et al., 2004). Vydrží pri aktivite len dovtedy, dokial' sa s ňou budú spájat' určité benefity, avšak aj tento druh motivácie je dôležitý a môže byt' vel'mi efektívnym prostriedkom používaným pri motivácii deti učit' sa hlavne $\mathrm{v}$ začiatkoch ich školskej dochádzky (Wigfield et al., 2004). Externe motivovaný jednotlivec sa zaujíma hlavne o verejné ohodnotenie svojich čitatel'ských úspechov, ako sú napríklad známky, získanie odmien, uznanie, prekonanie druhých (Katranci, 2015; Pečjak \& Košir, 2008; Guthrie et al., 2007; 
Wang \& Guthrie, 2004; De Naeghel et al., 2012; Paige, 2011; Lau, 2009) a podobne. Vonkajšie motivovaní jednotlivci častejšie používajú pri učení sa a čítaní povrchné stratégie, ako napríklad memorovanie, hádanie a referovanie nezmyselných viet. Tak isto majú problémy s čítaním s porozumením, nakol'ko tento druh motivácie sa u žiakov spája s menším množstvom času venovanému čítaniu pre potešenie a ich túžba porozumiet' čítanému textu nie je vysoká.

Vnútorná motivácia prináša na rozdiel od vonkajšej viac benefitov, medzi ktoré patrí napríklad vyššia miera sebaregulácie v čítaní, vytrvalost' v aktivite, porozumenie a psychická pohoda (De Naeghel et al., 2012). Je to práve ten druh motivácie, ktorý podl'a De Naeghel a kolektívu (2012) predstavuje najoptimálnejšiu formu motivácie práve pre svoju nezávislost' na vonkajších okolnostiach. Vnútorne motivovaní študenti čítajú pre čítanie samé bez vidiny externej odmeny (Katranci, 2015; Pečjak \& Košir, 2008; Pečjak \& Peklaj, 2006; Wigfield et al., 2004; Medford \& McGeown, 2012), čiže aktivita sama má pre nich osobnú hodnotu (McKool, 2007; De Naeghel et al., 2014; Wilson \& Casey, 2007; De Naeghel et al., 2012; Wang \& Guthrie, 2004). Dokážu dlhšie čelit’ problémom, ktoré sa v súvislosti s čítaním môžu objavit', k čomu dopomáha ich vzbudená vytrvalost' (Chiu \& Chow, 2010; Wang \& Guthrie, 2004). Táto vytrvalost' sa následne spája s vyšším akademickým úspechom. Čítajú podstatne častejšie a lepšie v porovnaní s ostatnými (De Naeghel et al., 2014; Paige, 2011; Wigfield et al., 2004; De Naeghel et al., 2012; Peklaj \& Pečjak, 2009; Wang \& Guthrie, 2004) a celkovo majú k čítaniu pozitívny postoj (Pečjak \& Peklaj, 2006).

$\mathrm{Na}$ vytvorenie pozitívneho postoja ku knihám a motivácie k čítaniu majú významný vplyv rodičia, ktorí by v tomto smere mali íst' svojím det'om príkladom (McKool, 2007; Wilson \& Casey, 2007). To preto, lebo rodičia sú významnými rolovými modelmi pre svoje deti (Wollschied, 2014). Dôležitost' rodiny čoby významnej skupiny l'udí, ktorá môže deti priviest' $\mathrm{k}$ čítaniu a aj ovplyvnit' ich motiváciu k vykonávaniu tejto aktivity potvrdzuje aj Trávníček (2008). Pre rozvoj motivácie čítat' je d'alej dôležitý, ba až nevyhnutný aj prístup ku knihám (McKool, 2007; Wilson \& Casey, 2007; Edmunds, 2003).

Motivácia čítat' sa v priebehu detstva a dospievania mení. Bolo zistené, že mladší žiaci čítajú preto, lebo chcú, aby ich za to rodičia (alebo aj iné autority) pochválili. Ďalšími dôvodmi sú dobré známky a sebaobraz ako o dobrom študentovi. Dôležité je aj to, že mladší žiaci základných škôl považujú čítanie za niečo, čo je pre budúcnost' potrebné a dôležité, pričom starší žiaci už tento názor nezdiel'ajú (Wolters et al., 2014; Pečjak \& Košir, 2008).

Počas prvého stupňa základnej školy majú deti najvyššiu motiváciu čítat', tu siahajú jej počiatky. Po prechode na druhý stupeň začína táto motivácia klesat' (Wilson \& Casey, 2007; Wolters et al., 2014; Edmunds, 2003; Paige, 2011), takže by sa dalo povedat', že motivácia čítat' je nepriamo úmerná veku, respektíve ročníku, v ktorom sa diet’a v rámci základnej školy nachádza (Wilson \& Casey, 2007; McGeown et al., 2015). Ako naznačuje výsledok výskumu, návyky k čítaniu vo vol'nom čase sa prestávajú formovat' okolo piateho a šiesteho ročníka. Návyky, ktoré si vypestujú do tohto obdobia si potom uchovávajú na celý život (McKool, 2007; Katranci, 2015), inak majú malé šance, že sa z nich vo vyšších ročníkoch stanú zanietení čitatelia (Pečjak \& Peklaj, 2006). Podporuje to aj Wollschied (2014), ktorá uvádza, že v desiatich rokoch sú deti už funkčnými čitatel'mi a tak sa u nich môžu vyvinút' relatívne stabilné čitatel'ské návyky vo vol'nom čase.

V poklese motivácie starších žiakov k čítaniu zohrávajú významnú úlohu aj zmeny prebiehajúce $\mathrm{v}$ adolescencii, ako napríklad uprednostňovanie aktivít zameraných na rozvoj sociálnych vzt’ahov s rovesníkmi, športovanie alebo využívanie sociálnych sietí a internetu 
pred aktivitami súvisiacimi so školou (Hidi, 2001; Wollschied, 2014; Lau, 2009). Motivácia čítat' nemusí byt' ani v adolescencii konštantná. V neskorších obdobiach si však jednotlivci môžu čítanie vážit' viac (Wilson \& Casey, 2007).

Ked’že tieto výskumy orientovali svoju pozornost' hlavne na porovnávanie motivácie k čítaniu medzi žiakmi prvého a druhého stupňa základných škôl, pričom starším adolescentom študujúcim na stredných školách bola venovaná pozornost' len v minimálnej miere, ciel'om tohto výskumu je porovnat' motiváciu k čítaniu medzi žiakmi druhého stupňa základných škôl, čiže mladšími adolescentmi, a žiakmi študujúcimi na stredných školách, čiže staršími adolescentmi. Na základe doterajších výskumov, ktoré poukazovali na to, že s narastajúcim vekom adolescentov klesá ich záujem o čítanie (Wilson \& Casey, 2007; McGeown et al., 2015) sa predpokladalo, že starší adolescenti budú k čítaniu menej motivovaní ako tí mladší. Ďalším ciel'om je aj zistenie najčastejších dôvodov pre a proti čítaniu kníh a preferencií u mladších a starších čítajúcich adolescentov.

\section{Výskumný súbor}

Výskumu sa zúčastnilo spolu 375 respondentov, z čoho zo základných škôl bolo 159 respondentov (42,4\%), zo stredných odborných škôl 150 (40\%) a zo štvorročných gymnázií 66 (17,6 \%). Výskumný súbor tvorilo spolu 246 dievčat $(65,6 \%)$ a 129 chlapcov $(34,4 \%)$. Vekové rozpätie celej vzorky bolo od 12 do 19 rokov $(\mathrm{M}=15,47 ; \mathrm{SD}=2,02)$. Vekový priemer mladších adolescentov bol 13,31 rokov ( $\mathrm{SD}=0,826)$ a starších adolescentov bol 17,06 rokov ( $\mathrm{SD}=0,784)$. Spolu $130(34,67 \%)$ respondentov uviedlo, že vo svojom vol’nom čase čítajú, pričom spomedzi nich bolo dievčat $106(81,54 \%)$ a chlapcov $24(18,46 \%)$.

Dáta boli zozbierané nenáhodným príležitostným výberom v období január - február 2016 hlavne na hodinách slovenského jazyka a na zastupovaných hodinách. Študentom trvalo vyplnenie dotazníka približne dvadsat' minút. Účast' na výskume bola dobrovol'ná. Podmienkou účasti na výskume bolo kompletné vyplnenie dotazníka.

\section{Použité metódy}

Na začiatok respondenti vyplnili základné demografické údaje. Po nich nasledovala položka zameraná na zistenie spôsobu trávenia vol'ného času. Respondenti v rámci nej mali zaznačit' 3-5 aktivít, ktorým sa venujú vo svojom vol’nom čase. Na základe spôsobov trávenia vol'ného času, ktoré respondenti uviedli v tejto časti boli rozdelení na dve skupiny. Prvú predstavovali respondenti, ktorí spontánne uviedli, že vo vol'nom čase čítajú knihy, teda čitatelia, zatial' čo druhú predstavovali jednotlivci, ktorí svoj záujem o čítanie kníh vo vol'nom čase nedeklarovali, teda nečitatelia. Pri rozdel'ovaní respondentov na tieto dve skupiny sa vychádzalo z predpokladu, že jednotlivec, pre ktorého je čítanie dôležitou aktivitou sa jej vo vol'nom čase aktívne venuje a tým pádom to bude jednou z aktivít, ktoré v rámci tejto položky uvedie.

Nasledujúcu čast' predstavoval dotazník zameraný na meranie motivácie k čítaniu Motivations for Reading Questionnaire (Wigfield \& Guthrie, 1997), ktorý je jedným z najčastejšie používaných dotazníkov na meranie motivácie k čítaniu (Conradi et al., 2014). Samotný dotazník pozostáva z 11 subškál, menovite: 1) Čitatel'ská sebaúčinnost', 2) Náročnost' čítania, 3) Čitatel'ský záujem, 4) Čitatel'ská zainteresovanost', 5) Dôležitost' čítania, 6) Vyhýbanie sa čítaniu, 7) Sút’aženie v čítaní, 8) Pochvaly za čítanie, 9) Čítanie na známky, 10) Sociálne dôvody vedúce k čítaniu a 11) Čítanie z donútenia. 
Tento dotazník je primárne zameraný na meranie motivácie k čítaniu prostredníctvom jednotlivých škál a pre potreby tejto práce bol upravený. Namiesto 53 položiek, ktoré tvoria dotazník bolo použitých len $31 \mathrm{z}$ nich. Dôvodom takéhoto skrátenia bolo prispôsobenie dotazníka ako našim kultúrnym podmienkam, tak aj vekovej kategórii našich respondentov, nakol'ko pôvodný dotazník bol určený na meranie motivácie k čítaniu kníh žiakov do 12 rokov. Odstránila sa subškála číslo 9 (Čítanie na známky), ktorá má opodstatnenie len na prvom stupni základných škôl, a aj otázky týkajúce sa čitatel'ských preferencii, sút’aženia v čítaní, vypracovávania domácich úloh z čítania a podobne. Respondenti odpovedali na otázky na štvorbodovej škále, ktorá predstavovala rozmedzie od vôbec ma to nevystihuje (1) po úplne ma to vystihuje (4). Vysoké hodnoty hrubého skóre naznačovali vysokú motiváciu pre čítanie. Po prepólovaní určených položiek nadobudla Cronbachova alfa pre celý dotazník hodnotu 0,897 a hodnoty Cronbachovej alfy pre jednotlivé škály sa pohybovali od 0,600 pre šiestu škálu po 0,801 pri škále číslo dva. Celková motivácia $\mathrm{k}$ čítaniu bola vypočítaná ako hrubé skóre $\mathrm{z}$ dát celého dotazníka. Pri hl'adaní rozdielov v motivácii k čítaniu medzi respondentmi sa už pracovalo so škálami samotnými a s ich hrubým skóre.

V rámci celého dotazníka dosiahlo hrubé skóre hodnotu 76,02 $(\mathrm{SD}=15,99 ; \min =36$; $\max =122)$, v rámci prvej škály $5,06(\mathrm{SD}=1,75 ; \min =2 ; \max =8)$, v rámci druhej škály $12,99(\mathrm{SD}=4,08 ; \min =5 ; \max =20)$, v rámci tretej škály $14,11(\mathrm{SD}=3,62 ; \min =5$; $\max =20)$, v rámci štvrtej škály $7,89(\mathrm{SD}=2,49 ; \min =3 ; \max =12)$, v rámci piatej škály 4,23 $(\mathrm{SD}=1,88 ; \min =2 ; \max =8)$, v rámci šiestej škály 11,37 $(\mathrm{SD}=2,81 ; \min =4$; $\max =16)$, v rámci siedmej škály $1,78(\mathrm{SD}=0,95 ; \min =1 ; \max =4)$, v rámci ôsmej škály $5,92(\mathrm{SD}=2,50 ; \min =3 ; \max =12)$, v rámci desiatej škály 9,43 $(\mathrm{SD}=3,55 ; \min =5$; $\max =20)$ a v rámci jedenástej škály $3,22(\mathrm{SD}=1,07 ; \min =1 ; \max =4)$. Detailnejšie hodnôty pre skupiny čitatel'ov a nečitatel’ov v rámci vekových skupín sú zobrazené v tab. 1 .

Tabul'ka 1 Hodnoty jednotlivých škál dotazníka MRQ pre skupiny čitatel'ov a nečitatel'ov $v$ rámci vekových skupín

\begin{tabular}{|c|c|c|c|c|c|c|c|c|c|}
\hline \multirow{2}{*}{\multicolumn{2}{|c|}{ MRQ }} & \multicolumn{4}{|c|}{ Mladší adolescenti } & \multicolumn{4}{|c|}{ Starší adolescenti } \\
\hline & & \multirow{2}{*}{$\frac{\mathbf{M}}{89,91}$} & \multirow{2}{*}{$\frac{\text { SD }}{14,08}$} & \multirow{2}{*}{$\begin{array}{c}\text { Min } \\
52 \\
\end{array}$} & \multirow{2}{*}{$\begin{array}{c}\text { Max } \\
122\end{array}$} & \multirow{2}{*}{$\frac{\text { M }}{86,16}$} & \multirow{2}{*}{$\frac{\text { SD }}{11,01}$} & \multirow{2}{*}{$\begin{array}{c}\text { Min } \\
60 \\
\end{array}$} & \multirow{2}{*}{$\frac{\text { Max }}{114}$} \\
\hline Collrox́́ HS & Čitatel’ & & & & & & & & \\
\hline & Nečitatel’ & 67,84 & 14,27 & 36 & 100 & 71,35 & 13,84 & 40 & 115 \\
\hline \multirow{2}{*}{ Prvá škála } & Čitatel' & 6,49 & 1,28 & 4 & 8 & 6,06 & 1,41 & 2 & 8 \\
\hline & Nečitatel' & 4,23 & 1,54 & 2 & 8 & 4,60 & 1,64 & 2 & 8 \\
\hline \multirow{2}{*}{ Druhá škála } & Čitatel’ & 15,75 & 3,31 & 8 & 20 & 15,27 & 3,19 & 8 & 20 \\
\hline & Nečitatel’ & 11,33 & 3,679 & 5 & 20 & 11,95 & 4,01 & 5 & 20 \\
\hline \multirow{2}{*}{ Tretia škála } & Čitatel’ & 15,47 & 3,08 & 8 & 20 & 15,39 & 2,87 & 7 & 20 \\
\hline & Nečitatel’ & 12,96 & 3,89 & 5 & 20 & 13,76 & 3,62 & 5 & 20 \\
\hline \multirow{2}{*}{ Štvrtá škála } & Čitatel’ & 9,92 & 2,14 & 3 & 12 & 9,05 & 2,22 & 4 & 12 \\
\hline & Nečitatel’ & 6,76 & 2,23 & 3 & 12 & 7,33 & 2,22 & 3 & 12 \\
\hline \multirow{2}{*}{ Piata škála } & Čitatel’ & 5,59 & 1,75 & 2 & 8 & 5,29 & 1,78 & 2 & 8 \\
\hline & Nečitatel' & 3,49 & 1,44 & 2 & 8 & 3,71 & 1,75 & 2 & 8 \\
\hline \multirow{2}{*}{ Šiesta škála } & Čitatel' & 12,26 & 2,86 & 6 & 16 & 11,55 & 2,70 & 5 & 16 \\
\hline & Nečitatel' & 10,53 & 2,97 & 4 & 16 & 11,57 & 2,57 & 6 & 16 \\
\hline
\end{tabular}




\begin{tabular}{|c|c|c|c|c|c|c|c|c|c|}
\hline \multirow{2}{*}{ Siedma škála } & Čitatel' & 2,02 & ,99 & 1 & 4 & 2,14 & 1,11 & 1 & 4 \\
\hline & Nečitatel' & 1,65 & ,91 & 1 & 4 & 1,59 & ,78 & 1 & 4 \\
\hline \multirow{2}{*}{ Ôsma škála } & Čitatel' & 7,25 & 2,71 & 3 & 12 & 6,45 & 2,24 & 3 & 12 \\
\hline & Nečitatel' & 6,00 & 2,51 & 3 & 12 & 5,06 & 2,24 & 3 & 12 \\
\hline \multirow{2}{*}{ Desiata škála } & Čitatel' & 11,32 & 3,62 & 5 & 18 & 11,22 & 3,21 & 5 & 20 \\
\hline & Nečitatel' & 8,16 & 3,09 & 5 & 17 & 8,70 & 3,37 & 5 & 17 \\
\hline \multirow{2}{*}{$\begin{array}{c}\text { Jedenásta } \\
\text { škála }\end{array}$} & Čitatel’ & 3,83 &, 54 & 1 & 4 & 3,72 & ,68 & 1 & 4 \\
\hline & Nečitatel' & 2,73 & 1,23 & 1 & 4 & 3,09 & 1,04 & 1 & 4 \\
\hline
\end{tabular}

$\mathrm{MRQ}=$ Dotazník zameraný na meranie motivácie k čítaniu (Motivations for Reading Questionnaire) HS= hodnota hrubého skóre; $M=$ priemer; $\mathrm{SD}=$ štandardná odchýlka; Min= minimum; Max= maximum

Ďalšiu čast’ administrovanej metodiky tvorili dve otázky: „Ak t’a čitanie baví, napís 3 dôvody, prečo“ a „Ak t’a čitanie nebaví, napíš 3 dôvody, prečo“. Tieto otázky boli otvorené a respondenti sa mohli slobodne vyjadrit' k dôvodom, ktoré ich k čítaniu privádzajú, respektíve odrádzajú. Zaznamenané odpovede respondentov na tieto položky boli podrobené obsahovej analýze, ktorej výsledkom boli kategórie týchto dôvodov, pre ktoré boli následne zist'ované ich frekvencie.

Dôvody, ktoré jednotlivcov vedú k čítaniu kníh boli vyhodnocované len v skupine respondentov, ktorí uviedli, že vo svojom vol'nom čase čítajú. Názvy kategórii, do ktorých bolo možné zaradit' uvedené dôvody, boli nasledovné: Nové informácie (získavanie nových, zaujímavých a často aj potrebných informácii), Predstavivost' (imaginácia), Únik z reality (nezat’ažovanie sa aktuálnymi problémami reálneho života), Oddych (relax), Dobrý spôsob trávenia času, Gramatika (zlepšovanie gramatiky, štylistiky, rozširovanie slovnej zásoby a podobne), Baví ma to, Je to zaujímavé, Lepšie ako iné aktivity, Nové myšlienky (týkajúce sa hlavne nových názorov a filozofie) a Ostatné.

Dôvody, ktoré jednotlivcov odrádzali od kníh, boli vyhodnocované len v skupine respondentov, ktorí uviedli, že vo svojom vol'nom čase nečítajú. Názvy kategórii, do ktorých bolo možné zaradit' uvedené dôvody, boli nasledovné: Nemám na to čas, Nebaví ma to, Nechce sa mi, Č́tanie je zdĺhavé, Č́tanie je nudné, Č́tanie je náročné, Radšej iné aktivity, Unavuje ma to a Ostatné.

V poslednej časti mali respondenti uviest' približný počet kníh, ktoré prečítajú za mesiac a aj žánre, ktoré ich zaujímajú. Ako predloha pri zostavovaní týchto žánrov slúžili kategórie, podl'a ktorých sú knihy rozdel'ované v Knižnici pre mládež mesta Košice, čiže konkrétne: 1) Náučná literatúra, 2) Fantasy, 3) Poézia, 4) Cudzojazyčná literatúra, 5) Dobrodružné príbehy, 6) Životopisné romány, 7) Romány pre dospelých, 8) Divadelné hry, 9) Príbehy o det'och, 10) Detektívky, 11) Príbehy o zvieratách, 12) Rozprávky, 13) Poviedky a novely, 14) Povesti, mýty, báje, legendy, 15) Dievčenské romány. Z týchto možností boli vylúčené príbehy o det'och a zoznam bol doplnený o žáner sci-fi, časopisy a možnost' Iné. Respondenti mohli zaznačit' l'ubovol'ný počet žánrov.

\section{Výsledky}

Ako ukazujú údaje v tabul'ke 2, výsledky štatistických analýz ukázali, že rozdiely v motivácii k čítaniu sa medzi staršími a mladšími adolescentmi nenachádzajú. Rozdiely neboli nájdené ani v rámci jednotlivých škál. 
Tabul'ka 2 Rozdiely v motivácii k čítaniu medzi staršími a mladšími adolescentmi

\begin{tabular}{|c|c|c|c|c|c|c|}
\hline \multirow{2}{*n}{} & \multirow{2}{*}{$\mathbf{N}$} & \multirow{2}{*}{$\begin{array}{c}\text { Priemerné } \\
\text { poradie }\end{array}$} & \multicolumn{3}{|c|}{ U-test } \\
\cline { 5 - 7 } & & & $\mathbf{U}$ & $\mathbf{Z}$ & $\mathbf{P}$ \\
\hline \multirow{2}{*}{ MRQ-HS } & MA & 159 & 181,75 & \multirow{2}{*}{16178,500} & $-0,958$ & \multirow{2}{*}{0,338} \\
\cline { 3 - 4 } & SA & 216 & 192,60 & & \\
\hline
\end{tabular}

MRQ-HS= hodnota hrubého skóre nameraná v dotazníku zameranom na meranie motivácie k čítaniu; MA= mladší adolescenti; $\mathrm{SA}=$ starší adolescenti

Rovnako tak sa nenašli signifikantné rozdiely v MRQ medzi mladšími a staršími čítajúcimi adolescentmi. Výnimku tvorila len škála číslo 4 (Čitatel’ská zainteresovanost'), kde sa ukázalo, že mladší čítajúci adolescenti sú do čítania viac zainteresovaní v porovnaní so staršími ( $\mathrm{p}=0,02)$, ako znázorňuje tabul'ka 3.

Tabul'ka 3 Rozdiely v motivácii k čítaniu medzi staršími a mladšími čítajúcimi adolescentmi

\begin{tabular}{|c|c|c|c|c|c|c|}
\hline & & \multirow{2}{*}{$\mathbf{N}$} & \multirow{2}{*}{$\begin{array}{c}\text { Priemerné } \\
\text { poradie }\end{array}$} & \multicolumn{3}{|c|}{ U-test } \\
\hline & & & & $\mathbf{U}$ & $\mathbf{Z}$ & $\mathbf{P}$ \\
\hline \multirow{2}{*}{$\begin{array}{c}\text { MRQ } \\
\text { 4. škála }\end{array}$} & MA & 53 & 74,66 & \multirow{2}{*}{1555,00} & \multirow{2}{*}{$-2,333$} & \multirow{2}{*}{0,020} \\
\hline & $\mathbf{S A}$ & 77 & 59,19 & & & \\
\hline
\end{tabular}

MRQ-HS= dotazník motivácie $\mathrm{k}$ čítaniu; $\mathrm{MA}=$ mladší adolescenti; $\mathrm{SA}=$ starší adolescenti

Graf 1 znázorňuje percentuálne zastúpenie jednotlivých dôvodov vedúcich žiakov k čítaniu. Zohl'adnené sú aj rozdiely medzi staršími a mladšími adolescentmi. Pre mladších adolescentov sú vel'mi motivujúce poznatky z kníh, ktorými sa pri čítaní môžu obohatit'. Túto možnost' označilo až 30,19 \% mladších adolescentov. Nasledujúce priečky najčastejších dôvodov vypovedali o tom, že jednotlivci sú $\mathrm{k}$ čítaniu vnútorne motivovaní, čiže ich to jednoducho baví $(28,30 \%)$ a čítanie považujú za zaujímavé $(26,42 \%)$. Rovnaké množstvo respondentov, ktorí označili posledný menovaný dôvod, súčasne uviedlo, že čítajú preto, aby mohlo na chvíl'u uniknút' $\mathrm{z}$ reality. Aj u starších adolescentov bol najčastejším dôvodom k čítaniu kníh záujem a túžba získavat’ nové informácie, uviedlo to až 44,16 \% respondentov. Následne nasledoval oddych (36,36 \%) a rovnako ako aj u mladších adolescentov, únik $\mathrm{z}$ reality $(26,42 \%)$.

V grafe 2 sú znázornené dôvody, pre ktoré respondenti vo svojom vol'nom čase nečítajú. Najčastejším dôvodom je u obidvoch skupín ten, že ich to nebaví, teda nie sú k tejto aktivite dostatočne motivovaní. Spomedzi mladších adolescentov uviedlo tento dôvod 33,96 \% a spomedzi starších 26,62 \% respondentov. Ďalšími dôvodmi, kvôli ktorým mladší adolescenti nečítajú, sú tie, že knihy považujú za nudné $(20,75 \%)$ a nechce sa im $(18,87 \%)$. Starší uviedli množstvo rozmanitých dôvodov, ktoré sme zaradili do možnosti Ostatné $(22,30 \%)$. Tretí najčastejší dôvod, prečo starší adolescenti nečítajú, je ten, že nemajú naň dost' času $(21,58 \%)$. 

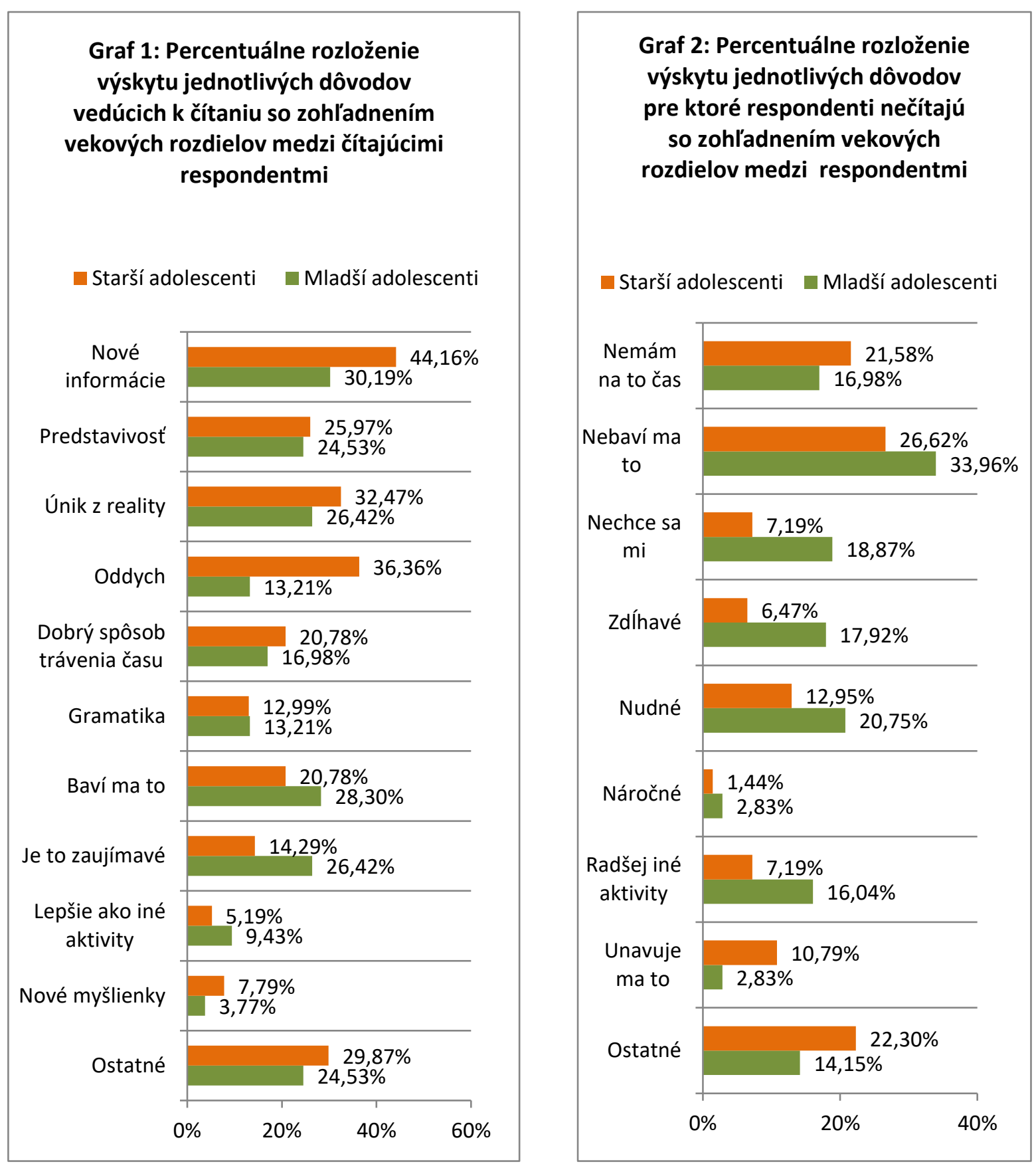


\section{Graf3: Percentuálne rozloženie výskytu preferovaných žánrov čítajúcimi respondentmi zohl'adňujúce vekové rozdiely}

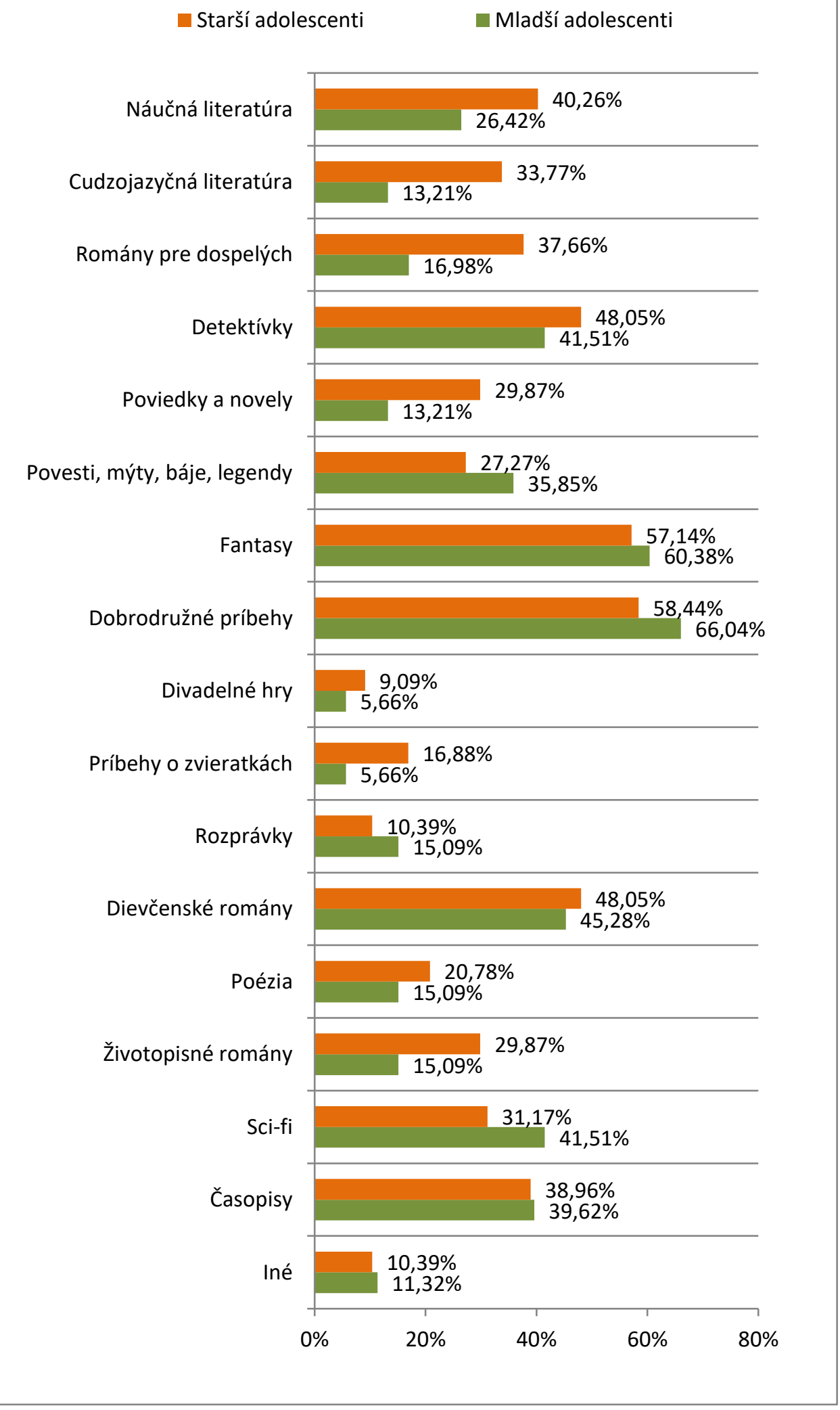


Na základe informácii z grafu 3 môžeme povedat', že mladší čitatelia najradšej čítajú romány dobrodružné $(66,04 \%)$ a fantasy $(60,38 \%)$. Tretím najpopulárnejším žánrom bol žáner určený hlavne pre dievčatá, čiže dievčenské romány $(45,28 \%)$, čo mohlo byt' v tomto prípade spôsobené tým, že vzorku čitatel'ov tvorili hlavne dievčatá. Preferencie starších sú takmer totožné s preferenciami mladších čitatel'ov. Aj v tejto skupine respondentov je najobl'úbenejším žánrom žáner dobrodružný $(58,44 \%)$, po ktorom nasleduje žáner fantasy $(57,14 \%)$. Zmena je len $\mathrm{v}$ tret'om najoblúbenejšom žánre, kde sú okrem dievčenských románov aj detektívky $(48,05 \%)$.

Štatisticky významný rozdiel $(\mathrm{p}=0,007)$ sa ukázal v množstve kníh, ktoré jednotlivci prečítajú $\mathrm{v}$ priemere za mesiac $(\mathrm{U}=1494,000 ; \mathrm{Z}=-2,679)$. Kým priemerný počet prečítaných kníh mladšími čitatel'mi dosahoval hodnotu 3,85 $(\mathrm{SD}=3,266)$, priemer u starších bol 2,51 $(\mathrm{SD}=2,075)$.

\section{Diskusia}

Jedným z ciel'ov tohto výskumu bolo zistit', či existujú rozdiely v motivácii k čítaniu medzi mladšími a staršími adolescentmi. Na základe doterajších výskumov sa predpokladalo, že starší adolescenti budú k čítaniu kníh motivovaní menej ako mladší (Wilson \& Casey, 2007; McGeown et al., 2015), čo sa však nepotvrdilo. Rozdiely medzi týmito dvoma skupinami adolescentov sa nepotvrdili v celkovej motivácii a ani v jednotlivých škálach dotazníka zameraného na meranie motivácie k čítaniu (Wigfield \& Guthrie, 1997). Tieto výsledky teda môžu dávat' za pravdu viacerým výskumom (Wollschied, 2014; Pečjak \& Peklaj, 2006; McKool, 2007; Katranci, 2015), ktoré poukazujú na to, že pokial' si jednotlivec vypestuje čitatel'ské návyky ešte počas prvých ročníkov základnej školy, jeho motivácia je relatívne konštantná aj v neskoršom období. Na sformulovanie takéhoto záveru však tento výskum nemá právomoc, ked’že je prierezového charakteru. V budúcnosti by bolo vhodné, keby sa tejto problematike venoval longitudinálny výskum, ktorý by si dal za ciel' sledovat' premeny motivácie $\mathrm{k}$ čítaniu $\mathrm{v}$ čase $\mathrm{u}$ jednotlivých respondentov.

Rozdiely medzi mladšími a staršími čitatel'mi sa našli len v množstve kníh, ktoré prečítajú v priemere za mesiac $(\mathrm{p}=0,007)$ a v škále číslo 4 (Čitatel'ská zainteresovanost') v rámci $M R Q$, čo poukazuje na to, že mladší čitatelia sú do čítania viac zainteresovaní ako tí starší. Priemerný počet prečítaných kníh za mesiac mladšími adolescentmi je 3,85 a staršími 2,51, čo je v silnom kontraste s výsledkom Trávníčkovho (2008) výskumu, podl'a ktorého v Česku čitatelia prečítajú za rok v priemere 16 kníh, čo by mohlo v priemere predstavovat' len 1,34 knihy za mesiac. Pri tomto porovnaní však netreba zabúdat' na to, že spomínaný výskum (Trávníček, 2008) bol realizovaný prevažne na dospelej vzorke, ktorá má na čítanie už v porovnaní s adolescentmi menej času. Predpokladáme, že mladší čitatelia v našej vzorke prečítajú viac kníh v porovnaní so staršími adolescentmi preto, lebo na ne majú viac času, ked’že minimálne v školskom prostredí sú na nich kladené menšie nároky a požiadavky ako je tomu v prípade starších čitatel'ov.

V rámci rodových rozdielov sa ukázalo, že spomedzi čítajúcich jednotlivcov tvoria dievčatá ovel'a väčšiu čast' ako chlapci $(81,54 \%$ vs. $18,46 \%)$, čo má podporu aj v iných výskumoch (Trávníček, 2008).

V niektorých výskumoch s ukázalo sa, že čitatelia očakávajú od čítania najčastejšie zábavu, napätie, informácie (Trávniček, 2008), čo bolo do istej miery podporené aj našim výskumom. Pri skúmaní motívov, ktoré vedú jednotlivcov k čítaniu kníh, obe skupiny čítajúcich adolescentov uviedli, že čítajú hlavne preto, lebo knihy pre nich predstavujú 
hodnotný zdroj nových informácii. Tieto informácie nepredstavujú len vedomosti, ktoré je možné zúročit' počas štúdia a premenit' na výborný prospech, na čo upozorňujú viaceré výskumy (Pečjak \& Peklaj, 2006; Wilson \& Casey, 2007; Lee \& Jonson-Reid, 2016). V jednotlivých literárnych žánroch je prezentovaná aj všeobecná l'udská múdrost' získaná zo skúseností z bežného života, ktorá im môže byt' nápomocná v orientovaní sa v okolitom svete.

Ďalším z hlavných motívov, ktorý vedie jednotlivcov k čítaniu kníh je oddych, ktorý je s touto aktivitou spojený, čo podporujú aj iní autori (Holomová, 2009). Tieto výsledky dokazujú, že čítanie je pre určitú skupinu l'udí skutočne hodnotným spôsobom trávenia vol'ného času.

Zaujímavým motívom vedúcim k čítaniu bol „Únik z reality“. S týmto motívom môžu úzko súvisiet' aj žánre, ktoré čítajúci respondenti označili ako svoje najoblúbenejšie a to žáner dobrodružný a fantasy, ktoré patrili k trom najobl'úbenejším žánrom v oboch skupinách adolescentov. Žiadané sú v tomto smere d’alšie výskumy, ktoré by sa zamerali na preskúmanie toho, pred čím čitatelia $\mathrm{z}$ reálneho sveta unikajú, či je to len túžba zažit' v knihách trochu nevšednosti a ozvláštnit' si tak vol’né chvíle, alebo či je čítanie ako také pre niektorých čitatel'ov istou formou terapie.

Berúc do úvahy tieto výsledky a tiež aj skutočnost', že čítanie stimuluje fantáziu jednotlivcov (Wilson \& Casey, 2007), bolo by vhodné venovat' pozornost' možnej existencii kvalitatívnych rozdielov vo fantázii, respektíve tvorivosti medzi jednotlivcami, ktorí čítajú knihy hlavne zo žánru fantasy, a tými, ktorí dajú prednost' klasickejším a realistickejším žánrom.

$\mathrm{Na}$ druhej strane stoja dôvody, pre ktoré jednotlivci knihy vo svojom vol'nom čase nečítajú. Mladší adolescenti sa čítaniu nevenujú hlavne preto, lebo čítanie ich nebaví (33,96\%), považujú to za nudnú aktivitu $(20,75 \%)$ a nie sú dostatočne motivovaní k tomu, aby sa o čítanie vôbec pokúsili, čo vyjadrili slovami „Nechce sa mi“ (18,87\%). Starších nečítajúcich adolescentov čítanie nebaví (26,62 \%), v druhom rade uviedli rozmanité dôvody, ktoré sa pre svoju rozmanitost' a vel'mi zriedkavý výskyt zaradili do skupiny s názvom „Ostatné“ $(22,30 \%)$ a do tretice uviedli, že na čítanie nemajú dost’ času (21,58\%). Aj z toho dôvodu je v spoločnosti rozšírený názor, že deti nečítajú a že ich preferencie spôsobov trávenia času sú orientované skôr na elektrotechnické vymoženosti dnešnej doby, ako sú napríklad počítačové hry alebo surfovanie po internete (Řeřichová, 2009). Ako sa však ukázalo v Trávníčkovom výskume (2008), hlavným nepriatel’om čítania nie je internet, ako by sme sa mohli domnievat', ale pasívne médiá, ako napríklad televízia alebo pozeranie filmov. Ďalej sa ešte ukazuje, že menej zanietení čitatelia prepadávajú týmto novodobým spôsobom trávenia vol'ného času v ovel'a väčšej miere ako tí zanietení (Trávníček, 2008).

$\mathrm{V}$ rámci výskumov orientovaných na čítanie, motiváciu $\mathrm{k}$ nemu a preferencie by sa pozornost' vedcov mohla zamerat' aj na dospelých, ked'že tejto skupine sa v tomto smere venuje vo výskume len minimum pozornosti. Dôležité je to aj z toho dôvodu, že sú to práve dospelí - rodičia, ktorí majú významný vplyv na formovanie motivácie k čítaniu a postoj ku knihám u detí (McKool, 2007; Wilson \& Casey, 2007; Wollschied, 2014). Aj výskum Trávníčka (2008) poukazuje na to, že jednotlivcov vedie k čítaniu vo významnej miere hlavne rodina (49\%) a následne škola a knižnica (18\%). Silu vplyvu rodinného prostredia dokázala vo svojom výskume aj Najvarová (2008), podl'a ktorej deti, ktoré boli často vystavované situáciám ako je predčítanie kníh rodičmi, obdarovanie knihami a pozorovanie rodičov pri čítaní mali vyššie skóre v testoch čitatel'skej gramotnosti ako deti, ktoré takýmto situáciám vystavené neboli. 
K limitom výskumu sa radí použitie upravenej verzie Guthrieho dotazníka na meranie motivácie k čítaniu - Motivations for Reading Questionnaire (Wigfield \& Guthrie, 1997), ktorý bol skonštruovaný pôvodne pre mladšie deti, $\mathrm{s}$ akými bolo pracované $\mathrm{v}$ rámci tohto výskumu. Do budúcna by bolo vhodné tento dotazník bud' kultúrne prispôsobit' československému prostrediu a tak isto ho aj upravit' pre potreby merania motivácie $\mathrm{k}$ čítaniu u staršej populácie, alebo vytvorit' úplne nový dotazník zameraný na meranie motivácie $\mathrm{k}$ čítaniu v našich podmienkach.

Vo všeobecnosti by bolo vhodné, ak by došlo k zjednoteniu názoru na to, kto je čitatel'. Je čitatel'om ten, kto prečíta minimálne jednu knihu za rok, ten, kto prečíta minimálne jednu knihu za mesiac alebo by malo byt' kritérium ešte prísnejšie? Výhodou by preto bolo aj vytvorenie citlivejšieho nástroja pre potreby diferenciácie respondentov na skutočných čitatel'ov, pre ktorých má táto aktivita skutočnú hodnotu a je pre nich prioritou, a tých, ktorí vo svojom vol'nom čase síce z času na čas niečo prečítajú, ale ovel’a radšej a vo väčšej miere dajú prednost' iným spôsobom trávenia vol'ného času.

\section{Záver}

Článok prináša informácie o motivácii mladších a starších adolescentov k čítaniu, dôvodoch, ktoré ich k tejto aktivite vedú a aj o preferovaných žánroch. Pozornost' je venovaná aj nečítajúcim adolescentom, kde bolo hlavným ciel'om odhalit' najčastejšie príčiny, ktoré jednotlivcov odrádzajú od tejto aktivity.

\section{Literatúra}

Abdullah, S., Rahim, P. R. M. A., Setia, R., Mohamad, R., Ghazali, N., Sabapathy, E., Nair, G. K. S., Muniandy, M. K., Theethappans, R., Hassan, W. A. W., \& Hassan, N. S. I. C. (2012). Reading for pleasure as a means of improving reading comprehension skills. Asian Social Science, 8(13), 233-238. https://dx.doi.org/10.5539/ass.v8n13p233

Conradi, K, Jang, B. G. \& McKenna, M. C. (2014). Motivation terminology in reading research: A conceptual review. Educational Psychology Review, 26, 127-164. https://doi.org/10.1007/s10648-013-9245-z

De Naeghel, J., Valcke, M., DeMeyer, I., Warlop, N., Van Braak, J., \& Van Keer, H. (2014). The role of teacher behavior in adolescents' intrinsic reading motivation. Reading and Writing, 27(9), 1547-1565. https://doi.org/10.1007/s11145-014-9506-3

De Naeghel, J., Van Keer, H., Vansteenkiste, M., \& Rosseel, Y. (2012). The relation between elementary students' recreational and academic reading motivation, reading frequency, engagement, and comprehension: A self-determination theory perspective. Journal of Educational Psychology, 104(4), 1006-1021. https://doi.org/10.1037/a0027800

Edmunds, K. M., \& Tancock, S. M. (2003). Incentives: The effects on the reading motivation of fourth-grade students. Reading Research and Instruction, 42(2), 17-37. https://doi.org/10.1080/19388070309558384

Guthrie, J. T., Hoa, A. L. W., Wigfield, A., Tonks, S. M., Humenick, N. M., \& Littles, E. (2007). Reading motivation and reading comprehension growth in the later elementary years. Contemporary Educational Psychology, 32(3), 282-313. https://doi.org/10.1016/j.cedpsych.2006.05.004

Hidi, S. (2001). Interest, reading, and learning: Theoretical and practical considerations. Educational Psychology Review, 13(3), 191-209. 
Homolová, K. (2008). Pedagogicko-didaktické a psychosociální aspekty pubescentního čtenářství. Ostrava: Ostravská univerzita.

Chiu, M. M., \& Chow, B. W. Y. (2010). Culture, motivation, and reading achievement: High school students in 41 countries. Learning and Individual Differences, 20, 579-592. https://doi.org/10.1016/j.lindif.2010.03.007

Katranci, M. (2015). Book reading motivation scale: Reliability and validity study. Educational Research and Reviews, 10(3), 300-307. https://doi.org/10.5897/ERR2014.1998.

Lau, K. L. (2009). Grade differences in reading motivation among Hong Kong primary and secondary students. British Journal of Educational Psychology, 79(4), 713-733. https://doi.org/10.1348/000709909X460042

Lee, Y. S., \& Jonson-Reid, M. (2015). The role of self-efficacy in reading achievement of young children in urban schools. Child and Adolescent Social Work Journal, 33, 79-89. https://doi.org/10.1007/s10560-015-0404-6

McGeown, S. P., Duncan, L. G., Griffiths, Y. M., \& Stothard, S. E. (2015). Exploring the relationship between adolescent's reading skills reading motivation and reading habits. Reading and Writing, 28(4), 545-569. https://doi.org/10.1007/s11145-014-9537-9

McKool, S. S. (2007). Factors that influence the decision to read: An investigation of fifth grade student's out-of-school reading habits. Reading Improvement, 44, 111-131.

Medford, E., \& McGeown, S. P. (2012). The influence of personality characteristics on children's reading motivation. Learning and Individual Differences, 22, 786791. https://doi.org/10.1016/j.lindif.2012.06.002

Morgan, P. L., \& Fuchs, D. (2007). Is there a bidirectional relationship between children's reading skills and reading motivation? Exceptional children, 73(2), 165183. https://doi.org/10.1177/001440290707300203

Najvarová, V. (2008). Čtenářská gramotnost žáků 1. stupně základní školy. Pedagogická orientace, 18(1), 7-21.

Paige, D. D. (2011). Engaging struggling adolescent readers through situational interest: A model proposing the relationships among extrinsic motivation, oral reading proficiency, comprehension, and academic achievement. Reading Psychology, 32(5), 395-425. https://doi.org/10.1080/02702711.2010.495633

Pečjak, S., \& Košir, K. (2008). Reading motivation and reading efficiency in third and seventh grade pupils in relation to teacher's activities in the classroom. Studia Psychologica, 50(2), 147-168.

Pečjak, S., \& Peklaj, C. (2006). Dimensions of reading motivation and reading achievement in 3rd and 7th grade students. Studia Psychologica, 48, 11-30.

Peklaj, C., \& Pečjak, S. (2009). Personal and environmental motivational factors that influence reading achievement in 3rd grade students in Slovenia. Studia Psychologica, 51(1), 21-34.

Pitcher, S. M., Albright, L. K., DeLaney, C. J., Walker, N. T., Seunarinesingh, K., Mogge, S., Headley, K. N., Ridgeway, V. G., Peck, S., Hunt, R., \& Dunston, P. J. (2007). Assessing adolescents' motivation to read. Journal of Adolescent \& Adult Literacy, 50(5), 378-396. https://doi.org/10.1598/JAAL.50.5.5

Roeschl-Heils, A., Schneider, W., \& van Kraayenoord, C. E. (2003). Reading, metacognition and motivation: A follow-up study of German students in grades 7 and 8. European Journal of Psychology of Education, 18(1), 75-86. https://doi.org/10.1007/BF03173605

Řeřichová, V. (2009). Nečtenářství jako sociální a profesní handicap. In Koudelková, E. (ed.), Současnost literatury pro děti a mládež. 17-24. Nakladatelství Bor.

Trávníček, J. (2008). Čteme? Obyvatelé České republiky a jejich vztah ke knize. Host. 
Wang, J. H., \& Guthrie, J. T. (2004). Modeling the effects of intrinsic motivation, extrinsic motivation, amount of reading, and past reading achievement on text comprehension between US and Chinese students. Reading Research Quarterly, 39(2), 162-186. https://doi.org/10.1598/RRQ.39.2.2

Wigfield, A., \& Guthrie, J. T. (1997). Relations of children's motivation for reading to the amount and breadth or their reading. Journal of Educational Psychology, 89(3), 420-432. https://doi.org/10.1037/0022-0663.89.3.420

Wigfield, A., Guthrie, J. T., Tonks, S., \& Perencevich, K. C. (2004). Children's motivation for reading: Domain specificity and instructional influences. The Journal of Educational Research, 97, 299-309. https://doi.org/10.3200/JOER.97.6.299-310

Wilson, J. D., \& Casey, L. H. (2007). Understanding the recreational reading patterns of secondary students. Reading Improvement, 44(1), 40-49.

Wollscheid, S. (2014). The impact of the leisure reading behaviours of both parents on children's reading behaviour: Investigating differences between sons and daughters. Poetics, 45, 36-54. https://doi.org/10.1016/j.poetic.2014.06.001

Wolters, C. A., Denton, C. A., York, M. J., \& Francis, D. J. (2014). Adolescents' motivation for reading: Group differences and relation to standardized achievement. Reading and Writing, 27(3), 503-533. https://doi.org/10.1007/s11145-013-9454-3

Yoğurtçu, K. (2013). The impact of self-efficacy perception on reading comprehension on academic achievement. Procedia-Social and Behavioral Sciences, 70, 375-386. https://doi.org/10.1016/j.sbspro.2013.01.075

\section{Údaje o autorkách}

Mgr. Nika Konrádyová, absolventka psychológie na Katedre psychológie UPJŠ v Košiciach, aktuálne doktorandka LF UPJŠ.

\section{Kontaktné údaje}

Adresa: Ústav verejného zdravotníctva a hygieny LF UPJŠ, Šrobárova 2, 04180 Košice

E-mail: n.konradyova@gmail.com

Mgr. Miriam Slavkovská, PhD. pôsobí ako odborná asistentka na Katedre psychológie UPJŠ v Košiciach, so zameraním na psychodiagnostiku a poruchy detského vývinu.

\section{Kontaktné údaje}

Adresa: Katedra psychológie FF UPJŠ v Košiciach, Moyzesova 9, 04001 Košice

E-mail: miriam.slavkovska@upjs.sk

Konrádyová, N., \& Slavkovská, M. (2021). Motivácia k čítaniu a čitatel’ské preferencie adolescentov. E-psychologie, 15(1), 1-15. https://doi.org/10.29364/epsy.390 